Apidologie, 1983, 14 (2), 119-125

\title{
EFFECT OF MID-SEASON CHANGE IN DIET ON DIET CONSUMPTION AND BROOD REARING BY CAGED HONEY BEES
}

\author{
E. W. HERBERT, Jr., and H. SHIMANUKI \\ U.S. Department of Agriculture, ARS, Bioenvironmental Bee Laboratory, \\ Belisville, Marvland 20705
}

\begin{abstract}
SUMMARY
The amount of brood rearing (area, $\mathrm{cm}^{2}$ ) and diet consumption by caged honey bees offered the following diets were measured : 1) Beltsville bee diet (BBD); 2) soybean (SB); 3) BBD for 6 wk, then SB for $6 \mathrm{wk} ; 4) \mathrm{SB}$ for $6 \mathrm{wk}$, then BBD for $6 \mathrm{wk}$; and 5) fresh pollen. For comparison, the rate of brood rearing in free flying colonies was measured.

After 12 weeks, bees offered pollen reared the most brood, followed in descending order of brood rearing by the free flying bees of fered $\mathrm{BBD}, \mathrm{SB} / \mathrm{BBD}, \mathrm{BBD} / \mathrm{SB}$, and finally $\mathrm{SB}$. The rate of brood rearing was affected by changing the diets after the sixth week. Bees offered SB/BBD reached their peak production early ( $w \mathrm{k} 4$ ) and then began to decrease production. After the change to $B B D$, the amount of brood increased from $51.6 \mathrm{~cm}^{2}(\mathrm{wk} 6)$ to $130.6 \mathrm{~cm}^{2}$ (wk 8). Bees offered BBD/SB continued to increase production from 129 to $134 \mathrm{~cm}^{2}$ when offered the SB diet and decreased production thereafter. Nutritional deficiencies apparently make the SB diet unacceptable for long feeding periods.

Generally, diet consumption was greatest early in the study and decreased with time. The pollen-fed bees consumed 97 percent of the diet offered, followed in decreasing order of diet consumption by bees offered BBD ( $88 \%)$, SB/BBD (79 \%), BBD/SB (77\%), and finally SB (63\%).
\end{abstract}

\section{INTRODUCTION}

Population density and brood rearing patterns in colonies of honey bees (Apis mellifera $\mathbf{L}$.), are broadly predictable according to the seasons but cannot be precisely predicted because they are often altered by quality and quantity of diet, temperature, climate, geographic location, and age of queens. One of the most complete studies on colony growth patterns was made by NOLAN (1925). NOLAN divided brood rearing cycles into a period of seasonal activity and a period of seasonal suspension. NOLAN further divided the active period into three phases : 1) 
initial expansion; 2) major expansion; and 3) final decline. More recent work on seasonal brood rearing activity in honey bee colonies was conducted by ALLEN (1965), FreE and RaCEY (1968), NELSON and JAY (1972), Avitabile (1978), Winston (1979, and PAGE (1981).

The brood rearing cycle for honey bees is probably controlled mainly by changes in day length Avitabile (1978). Herbert and Shimanuki (1978) showed that honey and pollen flows are less important factors since the brood rearing pattern for caged bee colonies fed pollen and syrup continually still followed the seasonal pattern for free flying colonies. Beekeepers often attempt to accelerate spring brood production by feeding pollen supplements and substitutes, but once abundant natural pollen is available, these diets probably have little effect on the colony. Since these diets tend to differ greatly in their biological potency, they also tend to differ in effectiveness when fed. The present study was an attempt to alter or modify the typical brood rearing pattern for caged bees by replacing their dietary pollen substitute with another in the middle of the brood rearing season. The two pollen substitutes tested were the Beltsville bee diet and a soybean preparation.

\section{MATERIALS AND METHODS}

Diets. - Six treatments were included in the 12 -week study, and each treatment was applied to four nuclei of bees. Five of the treatments involved offering caged bees one of the following diets: 1) Beltsville bee diet (BBD) (1);2) soybean (2) (SB); 3) BBD for $6 \mathrm{wk}$, then SB for $6 \mathrm{wk}$ (BBD/SB); 4) SB for $6 \mathrm{wk}$, then BBD for $6 \mathrm{wk}$ (SB/BBD); 5) fresh pollen collected from pollen traps placed on free flying colonies. For comparison, we recorded the rate of brood rearing in four free flying nuclei of bees (treatment 6 ) that foraged for their own food. The test ingredients in the prepared diets varied in protein level from $66 \%$ (BBD) to $49 \%$ (SB), but each diet in its final form contained $23 \%$ protein by adjusting the amount of sucrose and water. (HERBERT and ShIMANLKI 1978).

Experimental Conditions. - Individual nuclei were each established with $400 \mathrm{~g}$ of newly emerged Italian bees (ca. 4.000 bees) plus a mated laying queen (released 2 june 1981) and maintained in small hives $(23 \times 19 \times 27 \mathrm{~cm})$ normally used for queen mating. Each hive contained five drawn shallow combs $(3 \times 16 \times 24 \mathrm{~cm})$ free of any pollen or honey. Individual nuclei were placed in a screened flight cage $(2 \times 2 \times 2 \mathrm{~m})$ with $50 \mathrm{~g}$ of diet. The diet was placed in a plastic Petri dish lid $(15 \times 100 \mathrm{~mm})$ and the lid inverted over the top bars. Fresh water was provided in plastic trays containing small pebbles placed on the floor of each cage.

Diet and sucrose syrup (ad lib; $50 \% \mathrm{w} / \mathrm{v}$ ) were replaced weekly during the 12-week test, and the unused portion of the diet was weighed. After the first sealed brood appeared, the area of sealed cells was measured every second week, from 2 June through 24 August 1981, by using a wire grid with $6.45 \mathrm{~cm}^{2}$ divisions.

The data were analyzed by analysis of variance and differences were grouped by week according to Duncan's multiple range test.

(1) Beltsville bee diet was formulated by mixing $20 \mathrm{~g}$ of a Lactalbumin-Torula yeast mixture (1 part lactalbumin -2 parts yeast by weight) with $80 \mathrm{~g}$ sucrose. Water was added slowly until a moist patty could be formed. The final diet contained $13 \%$ protein on a dry weight basis.

(2) Toasted Nutrisoy T-6 from Archer Daniels Midland Co., Box 1470, Decatur, Illinois 62525. 


\section{RESULTS AND DISCUSSION}

Generally the bees increased brood production from week 2 until week 6 (Table 1). By the end of week 12, bees offered pollen had reared the most brood, followed in descending order of brood rearing by the free flying bees and the bees offered $\mathrm{BBD}, \mathrm{SB} / \mathrm{BBD}, \mathrm{BBD} / \mathrm{SB}$, and finally $\mathrm{SB}$. Of the nuclei fed pollen substitutes, those offered only $B B D$ reared the greatest amount of brood. The rate of brood rearing was affected by changing the diets after week 6 . Brood rearing by bees offered SB/BBD peaked early (week 4) and then began to decline. After the change to BBD, brood area increased from $51.6 \mathrm{~cm}^{2}$ (week 6) to $130.6 \mathrm{~cm}^{2}$ (week 8) and then decreased gradually until week 12. Bees offered BBD/SB continued to increase production for 2 weeks after the change to SB and then decreased production. This decrease was less severe than that for bees offered only SB diet for 12 weeks. Brood production by SB-fed bees peaked in week 6 and then decreased rapidly to an average of $6.5 \mathrm{~cm}^{2}$ by the end of week 12 . The SB diet sustained bees for short periods (up to 6 weeks), but nutritional deficiencies apparently make this diet unacceptable for longer periods.

Brood rearing by the free flying bees, considered the " most normal " in the test, began slowly as compared with that by pollen-fed caged bees. This finding, which agrees with findings in previous studies on caged and free flying bees, could have been due to the fact that newly emerged bees were used to establish the units and that several weeks are required before foragers can bring in enough pollen to meet a colony's requirements. The free flying bees eventually (week 8) reared the greatest amount of brood per 2 weeks and were only surpassed in total brood production only by caged bees offered pollen. Brood area for the free flying bees was $197 \mathrm{~cm}^{2}$ by the end of week 10 , but three of the four units had starved by the end of week 12. No attempt was made to feed these bees after the initial 2 weeks, during which they were fed sugar solution.

Caged bees offered pollen started brood rearing shortly after the units were established. Their brood production reached a maximum during week $4\left(206 \mathrm{~cm}^{2}\right)$ and decreased thereafter. On 24 August (week 12) the units averaged $135 \mathrm{~cm}$ of sealed brood.

Generally, diet consumption was greatest early in the study and decreased with time, the decrease being the most gradual for the pollen fed bees (Table 2). It was not possible to monitor the amount of pollen collected and consumed by the free flying bees. Each of the other groups was offered a total of $650 \mathrm{~g}$ of diet during the study. The pollen-fed bees consumed $97 \%$ of the diet offered followed in decreasing order of diet consumption by bees offered BBD (88\%), SB/BBD (79\%), BBD/SB $(77 \%)$, and finally SB (63\%).

Regardless of diet, bees seemed to consume less and consequently rear less brood with time. Bees offered pollen received it from a variety of floral sources 

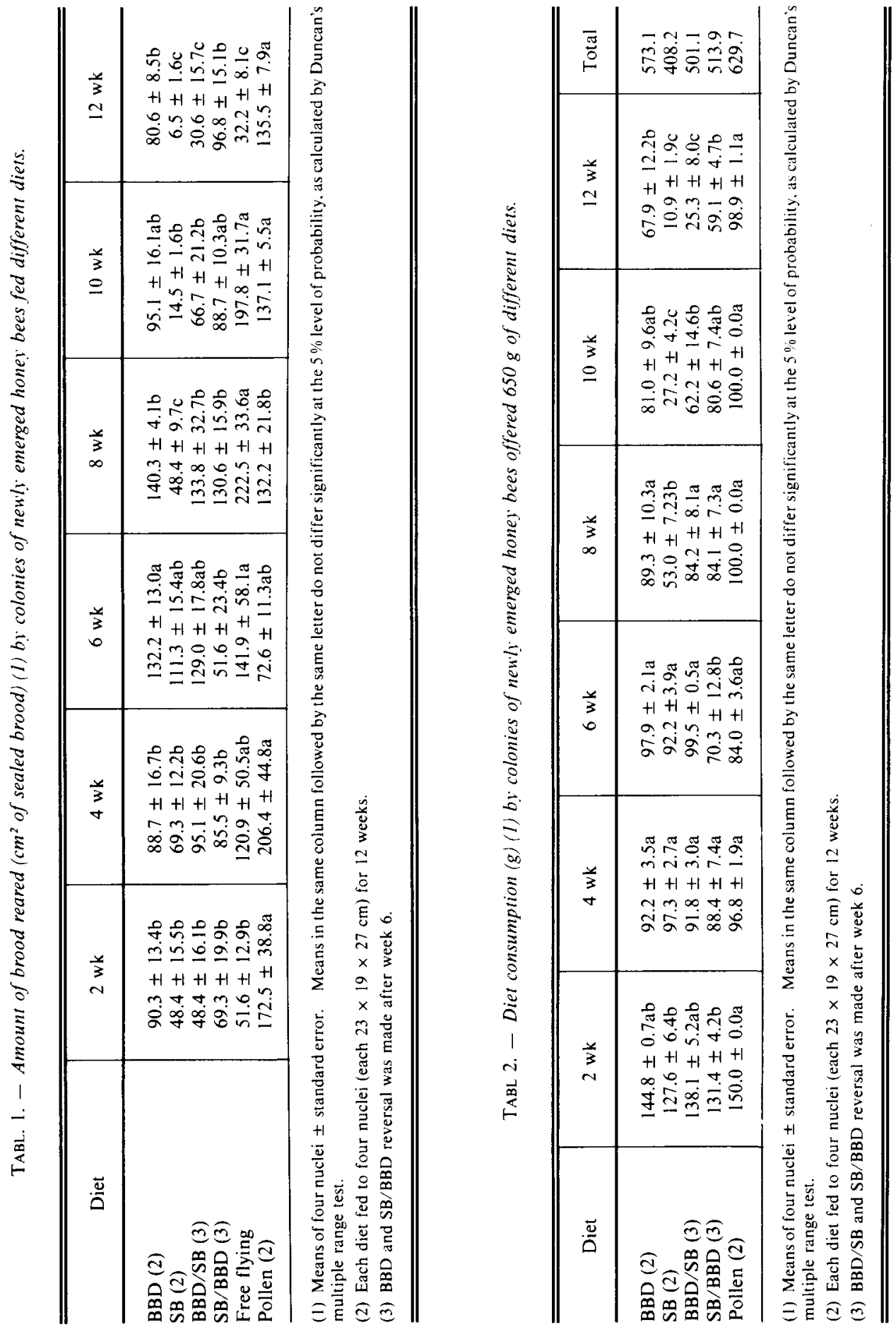
since it was offered shortly after collection from pollen traps. Changing the diet from SB to BBD increased diet consumption and stimulated brood production. possibly due to the new aroma and feeding stimulant made available to the nurse bees. The upsurge in consumption after changing from SB to BBD resulted in a significant increase in brood production. Soybean flour was an inferior diet for bees, as indicated by the continuous decline in brood rearing and consumption by bees offered BBD first, then SB. However, the decline in brood rearing and consumption was not as drastic as that for those units fed SB continually for 12 weeks.

Our study showed that brood production and demographic patterns are difficult to predict accurately since they differ from colony to colony, depending on the age and prolificacy of the queen, quality and quantity of incoming pollen and nectar, and the general condition of the colony. NOLAN (1925) noted that the four seasonal growth patterns in the colony are aften intermingled and difficult to distinguish. In this study the most " normal » condition would be in the free flying units. The caged, pollen-fed bees never experienced a pollen dearth since they were offered $50 \mathrm{~g}$ of pollen each week. We were able to modify the brood production by changing the diet regimes after 6 weeks. Certainly soybean flour alone for 12 weeks seemed to be unacceptable. By changing to the BBD, the rate of brood rearing increased significantly compared to SB. However, when offered a better diet (BBD) for 6 weeks then changing to SB for 6 weeks, the decrease in production was more evident though not as reduced as in the SB fed bees.

Changing of diets or pollen sources at the most opportune time may give beekeepers more control over their bees. Brood rearing can be maintained at a lower level early in the season and increased later by using appropriate natural pollen or substitutes. This technique of changing pollen substitutes may be especially useful in maintaining brood rearing in colonies kept in flight rooms. A free flying colony instinctively collects pollen from many plant sources and this may be one ot the reasons a high level of brood rearing can be maintained over a long period. It would be interesting to restrict free flying colonies to a single pollen source that would be available over a period of months and see if a decline in brood rearing can be reversed by another pollen source or pollen substitute.

The area of feeding stimulation requires much more research. Although attractants have been identified in pollen, we have not been able to use either the information obtained on attractants or the attractants themselves in our pollen substitute research. Our observations suggest that bees may " tire " of the same taste and aroma. Short-term colony stimulation may be accomplished by simply changing diets. However, using BBD alone (no switching) resulted in more brood than either switching treatment. 


\section{RÉSUMÉ \\ INFLUENCE DUN CHANGEMENT DE RÉGIME A LA MI-SAISON \\ SUR LA CONSOMMATION DU RÉGIME ET L'ÉLEVAGE \\ DU COUVAIN CHEZ DES ABEILLES ENCAGÉES}

La quantité de couvain élevé (surface en $\mathrm{cm}^{2}$ ) et la consommation du régime alimentaire par des abeilles encagées ont été mesurées selon le type de régime offert : 1) régime de Beltsville pour abeilles (BBD); 2) soja (SB); 3) BBD pendant 6 semaines puis SB pendant 6 semaines; 4) SB pendant 6 semaines, puis BBD pendant 6 semaines et 5) pollen frais. Le taux d’élevage du couvain dans des colonies en plein air a été mesuré à titre de comparaison.

Au bout de 12 semaines les abeilles auxquelles on avait offert du pollen ont élevé le plus de couvain, puis viennent par ordre décroissant les abeilles et les abeilles encagées libres nourries au BBD, au SB/BBD, au BBD/SB et en dernier par celles nourries au SB. Le taux d'élevage du couvain a été affecté par le changement de régime au bout de la 6e semaine. Les abeilles nourries avec le SB/BBD ont atteint rapidement (4e semaine) la production de pointe, puis ont commencé à moins produire. Après le changement pour le BBD, la surface de couvain est passée de $51,6 \mathrm{~cm}^{2}$ (6e semaine) à $130,6 \mathrm{~cm}^{2}$ (8e semaine). Les abeilles nourries avec le $\mathrm{BBD} / \mathrm{SB}$ ont continué à accroître leur production de couvain de 129 à $134 \mathrm{~cm}^{2}$ lorsqu'on leur a donné le régime SB. puis l'ont diminuée. Il semble que des déficiences nutritionnelles rendent le régime SB inacceptable pour de longues périodes de nourrissement.

D’une façon générale, la consommation du régime a été plus forte au début de l'étude puis a diminué avec le temps. Les abeilles nourries au pollen ont consommé $97 \%$ du régime offert; elles sont suivies par ordre décroissant des abeilles nourries au BBD $(88 \%)$, au SB/BBD (79\%), au BBD/SB (77\%) et en dernier lieu par celles nourries au SB (63\%).

\section{ZUSAMMENFASSUNG}

\section{EINFLUSS EINES WECHSELS DES FUTTERS IN DER MITTE DER AKTIVEN SAISON AUF FUTTERVERBRAUCH UND BRUTTÄTIGKEIT GEKÄFIGTER HONIGBIENEN}

Bei gekäfigten Honigbienen, welche folgendes Eiweißfutter erhielten, wurden der Umfang der Bruttätigkeit (Fläche in cm) und der Futterverbrauch gemessen : 1) Beltsville Bienen-Futtermischung (BBD); 2) Soyabohne (SB; = Toasted Nutrisoy T-6); 3) BBD 6 Wochen lang, dann 6 Wochen SB; 4) SB 6 Wochen lang, dann 6 Wochen BBD und 5) frischer Pollen. Zum Vergleich wurde die Brutaufzuchtrate in frei fliegenden Völkern gemessen.

Nach 12 Wochen zeigten die Bienen, denen Pollen geboten wurde, die meiste Brut gefolgt in absteigender Reihenfolge der Brutaufzuchtrate der frei fliegende Bienen durch BBD, SB/BBD, BBD/SB und zuletzt SB. Die Aufzuchtrate wurde durch den Wechsel der Futtermischung nach 6 Wochen beeinflußt. Bienen, denen SB/BBD angeboten wurde, erreichten ihre Höchstleistung früh (in der 4. Woche) und fielen dann ab. Nach dem Wechsel zu BBD steigerte sich der Brutumfang von $51.6 \mathrm{~cm}^{2}$ (in der 6. Woche) auf $130,6 \mathrm{~cm}^{2}$ (in der 8 . Woche). Bienen, denen BBD/SB angeboten wurde, steigerten ihre Leistung von $129 \mathrm{zu} 134 \mathrm{~cm}^{2}$, wenn $\mathrm{SB}$ angeboten wurde, und verringerten sie danach. Nährwert-Mängel machen die SB-Mischung augenscheinlich unakzeptable für längere Fütterungsperioden.

Generell war der Verbrauch an Futtermischung am größten zu Beginn der Studie und nahm über die Zeit hin ab. Die mit Pollen gefütterten Bienen verbrauchten $97 \%$ der angebotenen Menge, gefolgt in absteigender Reihenfolge des Verbrauchs von BBD (88\%), SB/BBD (79\%), BBD/SB (77\%) und zuletzt SB (63\%). 


\section{LITERATURE}

ALLEN M. D., 1965. - The effect of a plentiful supply of drone comb on colonies of honey bees. J. Apic: Res., 4. 109-119.

Avitabile A., 1978. - Brood rearing in honey bee colonies from late autumn to early spring. J. Apic. Res., 17, 69-73.

FreE J. B and P. A. RACEY, 1968. - The effect of the size of honey bee colonies on food consumption, brood rearing and the longevity of the bees during winter. Entomol. Exp. and Appl., 11, 241-249.

Herbert E. W. Jr., and H. Shimanuki, 1978. - Effect of the size of outdoor flight cages on brood rearing and food consumption by honey bees. J. Apic. Res.. 17, 114-117.

NeLson D. L. and S. C. JAY, 1972. - Population growth and honey yield studies of package bee colonies in Manitoba. II. Colonies initiated with four package sizes on one date. Manit. Enomol. 6 17-22.

NoLAN W. J., 1925. - The brood-rearing cycle of the honey bee. Bull. U.S. Dept. Agric., No. 1349.

PAGE R. E. Jr., 1981. - Protandrous reproduction in honey bees. Emiron. Entomol. 10, 359-362.

Winston M. L., 1979. - Intra-colony demography and reproductive rate of the Africanized honey bee in South America. Ecol. Sociol. 4, 279-292. 